6014

Research Article

Journal of Extension Education

Vol. 30 No. 1, 2018

DOI:https://doi.org/10.26725/JEE.2018.1.30.6014-6018

\title{
Risk Assessment in Specialised Home gardens of Kerala
}

\author{
C. Sreelakshmi ${ }^{1}$
}

\begin{abstract}
Home gardens have emerged as the best agricultural production system in Kerala due to limiting land availability and the shrinking operational land unit. Time and act of commercialization have transformed the homegardens to more diversified and specialized home gardens. A critical study of risks in the specialized homegarden production systems is the need of the hour to enhance its productivity. This paper analyses the various risk factors in home gardens.
\end{abstract}

Keywords : Risk assessment; specialized home garden; productivity; Kerala

\section{INTRODUCTION}

Specialised home gardens can be operationalised as the agricultural production system practiced around home or in extended area comprising multiple plant species inclusive of specialised components like sericulture, animal husbandry, apiculture, aquaculture etc. which can contribute to additional income generation to meet needs of home and as well cultivated in commercial scale in case of surplus production. The analysis of risks and identification of constraints would definitely prove to make the production system more remunerative. Hardarkar et al. (2004) stated that market risks stems out from unpredictable currency exchange rates. Risk is prevalent in agriculture and despite widespread use of risk management strategies there is need for continued outreach and research to further mitigate its effects. Meuwissen et al. (2001) studied farmers perceptions of risk and risk management and showed that price and production factors were perceived as important sources of risks. According to Holton, (2004) Risk or the "exposure to a proposition in which one is uncertain" is customary in agriculture due to continual political, economic, and social change, as well as exposure to weather and market variation.

Therefore specialized home garden is a system that can overcome current limitations of time, space and capital that should be triangulated with effective extension interventions at ground level for the overall remunerativeness and sustainability of home gardens. The present study was taken up with the following objectives.

- To assess the various risks encountered in specialized home gardens.

- To estimate the overall risks associated with specialisations under study.

1 - PhD Scholar, Agricultural Extension, Swami Keshwanand Rajasthan Agricultural University, Rajasthan 334006

Received : 12-10-2018; Accepted : 24-10-2018 


\section{METHODOLOGY}

The study was conducted in the Thiruvanathapuram district in Kerala where the specialized home garden systems are in vogue. A total of 60 potentially active specialized home garden farmers were identified using simple random sampling.

Risk assessment of home garden farmers engaging with specialized components was assessed using the risk attitude scale developed by New England Small Farm Institute, Cornell University, Belchertown, Massachusetts with slight modifications. The scale consists of 33 statements under 5 Dimensions categorized as high (3), moderate (2) and low (1). Quartile analysis was used to estimate the different type of risks. Also, the entire risks were estimated for different specialisations. The maximum and minimum score was 15 and 7 respectively. A chi-square analysis was done to estimate any significant difference among the risks associated with specialisations. Similarly constraints were worked out using mean cumulative index and perceived solutions were documented. The period of the study was two years from 201617 to 2017-18.

\section{FINDINGS AND DISCUSSION}

\section{Production risks}

An overall analysis of production risks among the specialised home garden farmers reveals that 40 percent face low risk, 51.6 face moderate risk and 8.3 per cent face high risk. Crop and livestock performance also depend on biological processes that are affected by the weather and pests \& diseases. Hail or heavy rains could damage or even wipe out crops. Outbreaks of pests or diseases could also cause major yield losses in crops and livestock. Risk factors especially in homesteads are quite high. Specializations helps to curb risks to certain effect and horizontal and vertical integrations manage the risk effectively.

Table 1.

Distribution of Respondents Based on Production Risks

\begin{tabular}{|l|c|c|}
\hline \multicolumn{1}{|c|}{ Category } & Frequency & Percentage \\
\hline Low $(<7)$ & 24 & 40.0 \\
\hline $\begin{array}{l}\text { Moderate } \\
(7-9)\end{array}$ & 31 & 51.6 \\
\hline High (>9) & 5 & 8.3 \\
\hline
\end{tabular}

\section{Marketing Risks}

Marketing risk includes risks related to pricing, product development, distribution especially in case of value addition. Here 11.7 per cent face low risk, 63.4 per cent have moderate risk and 25 per cent have high risk. Comparatively high risks (25 per cent ) can be due to the fact that avenues for product diversification and value addition are lacking in specialised home gardens unlike traditional home gardens.

Table 2.

Distribution of Respondents Based on Marketing Risks

\begin{tabular}{|l|c|c|}
\hline \multicolumn{1}{|c|}{ Category } & Frequency & Percentage \\
\hline Low $(<9.50)$ & 7 & 11.7 \\
\hline $\begin{array}{l}\text { Moderate }(9.50- \\
\text { 14) }\end{array}$ & 38 & 63.4 \\
\hline High (>14) & 15 & 25 \\
\hline
\end{tabular}

\section{Financial Risks}

Financial risk results when the farm business 
borrows money and creates an obligation to repay debt. Rising interest rates, the prospect of loans being called by lenders and restricted credit availability are also aspects of financial risk. Results reveal that 19 per cent are under low risk, 31 per cent under moderate risk, 10 per cent under high risk.

Table 3.

Distribution of Respondents Based on Financial Risks

\begin{tabular}{|c|c|c|}
\hline Category & Frequency & $\begin{array}{c}\text { Per } \\
\text { centage }\end{array}$ \\
\hline Low $(<10.00)$ & 19 & 31.7 \\
\hline $\begin{array}{c}\text { Moderate (0.00- } \\
14.00)\end{array}$ & 31 & 51.7 \\
\hline High (14.00+) & 10 & 16.7 \\
\hline
\end{tabular}

\section{Legal and Environmental Risks}

Legal risks relate to fulfilling business agreements and contracts. Failure to meet these agreements often carry a high cost. Another major source of legal risk is liability causing injury to another person or property due to negligence.

Table 4.

Distribution of Respondents Based on Legal and Environmental Risks

\begin{tabular}{|c|c|c|}
\hline Category & Frequency & $\begin{array}{c}\text { Per } \\
\text { centage }\end{array}$ \\
\hline Low (<10) & 19 & 31.7 \\
\hline Medium (10-12) & 34 & 56.7 \\
\hline High (>12) & 7 & 11.7 \\
\hline
\end{tabular}

Lastly, legal risk is closely related to environmental liability and concerns about water quality, erosion and pesticide use. The results revealed that 31.7 per cent are under low risks, 56.7 per cent face moderate risks and 11.7 per cent face high risks. From this, we can infer that farmers are following good agricultural practices which prevent harnessing the environment and legal ethics

\section{Human Resource Risk}

Human resource risks pertain to risks associated with individuals and their relationships to each other. These relationships include those with family members, as well as farm employees and customers. Key sources of human resource risk arise from one of the "three D's" - divorce, death, or disability. The impact of any of these events can be devastating to a farm. Human resource risks also include the negative impacts arising from a lack of people management skills and poor communications. The implication of the result is that nearly 31.7 per cent are under low risk, 51.7 per cent face moderate risk and 16.7 per cent face high risks. It is evident that high per cent (31.7 per cent) of the home garden respondents face lower risks when compared to other type of risks.

Table 5.

Distribution of respondents based on human resource risks

\begin{tabular}{|c|c|c|}
\hline Category & Frequency & $\begin{array}{c}\text { Per } \\
\text { centage }\end{array}$ \\
\hline Low (<10.00) & 19 & 31.7 \\
\hline $\begin{array}{c}\text { Moderate } \\
(10.00-14.00)\end{array}$ & 31 & 51.7 \\
\hline High (14.00+). & 10 & 16.7 \\
\hline
\end{tabular}

Risk assessment in specialisations

Specialisations when done with commercial interest can lead to different types of risk. Hence an attempt was made to draw risk 
Risk Assessment in Specialised Home gardens of Kerala

assessment in specialisations and the results are presented in Table 6.
The overall risk assessment in specialisations are depicted in Table 6.

Table 6.

Risks Assessment in Specialisations

\begin{tabular}{|c|c|c|c|c|c|c|c|c|}
\hline $\begin{array}{l}\text { Specialised } \\
\text { Component }\end{array}$ & $\begin{array}{l}\text { Pdn } \\
\text { risk }\end{array}$ & $\begin{array}{l}\text { Ptn } \\
\text { risk }\end{array}$ & $\begin{array}{l}\text { Va } \\
\text { risk }\end{array}$ & $\begin{array}{l}\text { Mk } \\
\text { risk }\end{array}$ & $\begin{array}{c}\mathrm{Fi} \\
\text { risk }\end{array}$ & $\begin{array}{l}\text { Le } \\
\text { risk }\end{array}$ & $\begin{array}{l}\mathrm{Hu} \\
\text { risk }\end{array}$ & $\begin{array}{l}\text { Total } \\
\text { risks }\end{array}$ \\
\hline Vegetables (8) & 9.88 & 14.13 & 10.00 & 10.00 & 10.25 & 8.36 & 8.25 & 70.86 \\
\hline Poultry (4) & 12.41 & 13.54 & 9 & 13.24 & 13.41 & 13.23 & 9 & 83.83 \\
\hline Livestock - cow(3 & 12.21 & 14.52 & 9.11 & 12.85 & 12.83 & 8.63 & 8.13 & 78.28 \\
\hline $\begin{array}{l}\text { Animal } \\
\text { Husbandry-(6) }\end{array}$ & 12.54 & 12.2 & 9.34 & 13.65 & 13.14 & 10.42 & 8.25 & 79.54 \\
\hline Goat-(1) & 9.37 & 9.27 & 12.54 & 12.41 & 13.52 & 9.41 & 11.47 & 77.99 \\
\hline $\begin{array}{l}\text { Aquaculture/Farm } \\
\text { tourism-(7) }\end{array}$ & 12.21 & 14.23 & 10.21 & 11.23 & 14.32 & 13.14 & 9.25 & 84.59 \\
\hline Banana-(6) & 10.21 & 11.23 & 8.23 & 10.21 & 11.87 & 8.62 & 8.47 & 68.84 \\
\hline Coconut -(4) & 10.21 & 11.35 & 8.62 & 12.35 & 9.11 & 8.11 & 12.14 & 71.89 \\
\hline Tubers-(2) & 10.41 & 10.11 & 9.13 & 13.52 & 9.68 & 8.41 & 8.96 & 70.22 \\
\hline Fruit trees $-(2)$ & 9.32 & 10.26 & 10.41 & 12.87 & 9.32 & 8.32 & 9.28 & 69.78 \\
\hline Rubber -(3) & 9.68 & 8.63 & 9.23 & 11.63 & 9.11 & 12.85 & 10.17 & 71.30 \\
\hline Mushroom-(1) & 14.21 & 13.21 & 10.62 & 14.22 & 11.68 & 9.65 & 8.11 & 81.70 \\
\hline Terrace garden-(3) & 12.24 & 9.36 & 10.23 & 13.21 & 10.87 & 8.25 & 7.52 & 71.68 \\
\hline Orchids-(1) & 12.11 & 11.23 & 13.21 & 13.58 & 13.98 & 10.11 & 12.19 & 86.41 \\
\hline Ornamentals -(4) & 12.35 & 10.35 & 12.11 & 14.32 & 13.57 & 8.12 & 12.87 & 83.69 \\
\hline Apiary-(1) & 11.2 & 12.11 & 8.93 & 12.58 & 12.52 & 13.52 & 10.21 & 81.07 \\
\hline Total risks & 195.6 & 199.2 & 172.0 & 213.72 & 203.4 & 169.2 & 162.2 & 1315.6 \\
\hline \multicolumn{3}{|c|}{ Pdn -Production risk } & \multicolumn{6}{|c|}{ Fi- Financial risk } \\
\hline \multicolumn{3}{|l|}{ Ptn -Protection risk } & \multicolumn{6}{|c|}{ Le- Legal \& environmental risk } \\
\hline \multicolumn{3}{|c|}{ Va-Value addition risk } & \multicolumn{6}{|c|}{ Hu- Human resource risk } \\
\hline \multicolumn{9}{|l|}{ Mk-Marketing risk } \\
\hline \multicolumn{3}{|c|}{ Chi-square (Observed value) } & \multicolumn{6}{|l|}{21.86} \\
\hline \multicolumn{3}{|c|}{ Chi-square (Criticalvalue) } & \multicolumn{6}{|c|}{119.81} \\
\hline \multicolumn{3}{|l|}{ DF } & \multicolumn{6}{|l|}{96} \\
\hline \multicolumn{3}{|l|}{$p$-value } & \multicolumn{6}{|l|}{1.000} \\
\hline \multicolumn{3}{|l|}{ alpha } & \multicolumn{6}{|l|}{0.05} \\
\hline
\end{tabular}


From Table 6, we can infer that on analysis of risks it was found that maximum risks was for homegarden with floriculture (orchids) as specialisation (86.41) followed by aquaculture (84.59), poultry (83.33) and the least was observed for banana (68.84) as perceived by the farmers with specialisations.

However an analysis of the different type of risks in relation to the different specialisations, revealed that for crop based specialisations, protection risks (14.12) was the highest followed by value addition (10). In case of animal husbandry components, marketing risks (13.65) was highest followed by financial risks (13.14) and for fisheries, financial risks (14.32) was highest followed by protection risks (14.23). For other components, marketing risk (14.32) was highest followed by financial risks (13.57). Further the results of the risk assessment for different specialisations with respect to production, marketing, financial, legal and environmental risks and human resource risks revealed that marketing risks was the highest with a score of 213.72 and legal and environmental risks was perceived to be least with a score of 162.27 . This is because marketing risks tends to be highest in home gardens inclusive of specialisations.

Since the computed $\mathrm{p}$ value is greater than the significance level alpha $=$
0.05 , there exists no significant difference among specialisations and total risks. This is due to the fact that risks are independent of the specialisations. Different specialisations may encounter different risks at various time right from its production stage till marketing.

\section{CONCLUSION}

This study had identified the various risks encountered in specialized home gardens and the overall risks associated with the specialization in the home gardens. These results need to be taken in to account by the extension agencies for improving remunerativeness \& sustainability of home gardens.

\section{REFERENCES}

Hardaker, J. B., Huirne, R.B.M., Anderson, J. R., \& Lien, G. (2004).Coping with Risk in Agriculture.Second Edition. Cambridge, Massachusetts, CABI Publishing 50p

Holton, G. A. (2004). Defining risk.Financial Analysts Journal 60 (6): 19-25.

Meuwissen, M. P. M, Huirne, R.B.M \& Hardarkar,J.B (2001). Risk and management .An empirical analysis of Dutch Livestock farmers. Livestock Production Science. 69(1): 43-53. 